\title{
A Case Study of Emplacement and Education in Jiangxi Province: based on Local Governance Theory and New Public Service Theory
}

\author{
Pan Songting ${ }^{1, a}$, Yang Dapeng ${ }^{2, b}$ and Cui Jin ${ }^{2, c}$ \\ ${ }^{1}$ Party school of Zhejiang provincial committee the CPC, Hangzhou, China \\ ${ }^{2}$ School of public affairs, Zhejiang University, Hangzhou, China \\ apansongting315@163.com byangdp@zju.edu.cn c petercui@zju.edu.cn
}

Keywords: local governance theory, new public service theory, policy making mechanism

\begin{abstract}
The process of public policy formulation involves the participation of many actors. Through on the case study of Emplacement and Education improved by the Justice Department of Jiangxi Province, the framework of the policy making mechanism is built, and the mechanism of public policy formulation is further explored based on local governance theory and new public service theory. The system of local government public policy formulation of the way and multi participation model is also elaborated.
\end{abstract}

\section{Introduction}

Public policy is the principled guide to action taken by the administrative executive branches of the state with regard to a class of issues in a manner consistent with law and institutional customs. The formulation and evolution of public policy is a hot topic in public management. It has been an important perspective to observe and study the practice of public management that how public issues come to sight of actors, how policies are designed and chosen, and what kind of circumstances will make changes and so on. Due to the evolution of public policy in the process of problem identification, agenda setting, policy formation and the legalization of each phase are all around the decision-making process. Therefore, the problem of public policy decision making is not only concerned by the academic circles, but also in the public management practice. People try to promote the scientific of decision-making mechanism through reform.

China has a complex inter governmental relations and organization network, while the target of multiple participants may be different and conflicting. Therefore, the policy formulation in the vertical and horizontal has the high dynamic and complex characteristics, which leads to the hierarchy and multi attributes characteristics of China's public policy. The formulation of public policy related to the adjustment and redistribution of the interests of different groups tend to break the original balance of interests, which will cause great conflicts. Benefit groups will take some action to maintain and support the public policy that is beneficial to their own, while the damaged group will try to oppose or change its own public policy. Therefore, the public participation in public policy formulation is essentially a game process of different interest groups to participate in the public interest. It is of far-reaching theoretical and practical significance to provide the system guarantee for the social public participation in public policy formulation for realizing the public policy of scientific, democratic, and improve the quality of public policy formulation.

\section{Mechanical Analysis of Public Policy Making}

\section{Constitution of Public Policy Formulation}

Subject of public policy

As one of the elements of the policy making system, the content of public policy subject includes the effective path and the effective mechanism of the public policy subject and the main body of the subject. According to the political influence and the difference of resources possession, the main policy is divided into three parts: namely, political institutions, interest groups and citizens. Political institution is the main body of the public policy. It is absolute majority of the society, which has a 
strong influence on the distribution of social resources, such as: political parties, legislative bodies, administrative bureaucracy, etc.

The interest group is a social group which has the specific interests of common interests, and tries to realize and safeguard their own interests by affecting the government's policies and actions. It includes a group of interest groups with a certain rule and organization structure, also includes a large number of loose, lack of organization form of interest group type. For example, interest groups may base on race, language, religion, region and occupation, as well as the basis of family relationship. Citizens are not only the subject but also the object of public policy. Citizens participate in the country's political system through various means, and try to influence or restrict the formulation and implementation of the government's public policy.

The Influence of Public Policy Making on the Subject of Public Policy

In political institutions, because of the exercise of public power, the government is the most important policy subject. It will use all kinds of power to influence the policy process. Interest groups will use their own interests, professional functions and political institutions to carry out the needs, preferences and interests of the exchange and the game, so that their interests can be expressed and realized. And the citizens generally participate in the political life through the influence of the public policy, which can affect the political system structure, operation mode, operating rules and policy process. It has important role in the scientific and democratic process of public policy formulation.

\section{Dynamic Process of Public Policy Formulation}

Public policy formulation is a dynamic process of government leading as well as interests conflict, coordination and compromise between the subjects of public policy. Dror regards it as the life procedure of the whole public policy in general. It includes policy formulation stage and post policy formulation stage which means that it is mainly divided into three steps: policy issues, the establishment of the policy agenda, policy planning and policy legalization.

\section{Confirmation of Policy Issues}

The main function of the government and the leading role of public policy is to solve many problems in society, so that the objective existence of social problems and the subjective identification are generally considered to be the starting point of the policy formulation process. When a social issue comes into the policy agenda, it will become a policy issue. Only when most members of the society and part of big shots believe that some social situation is a social problem, it will become a social problem, and the power factor plays a very important role. The focus and attitude of some influential elites such as government officials, economic elites, cultural elites, or interest groups sometimes can put a social situation directly to the social problems of the stage. What's more, people's subjective understanding, ideological beliefs, life attitude and other factors in the formation of social problems have a decisive impact. In public choice theory, as the information is not complete and interest expression channels are not smooth or other reasons, the policy issue is even more determined by the preference of a strong interest group.

Establishment of Policy Agenda

Policy agenda is the procedure to put policy issues into the process of the action plan for the political or policy institutions, which provides a channel of policy issue coming into the policy process and some other problems to think about. From the general social problems to the more concentrated public issues and finally the public policy problem, it varies with the social situation, economic situation and social forces, the group of these issues reflected by preference, needs, and values. The establishment of the policy agenda is a key step of social issues turning into policy issues.

The legalization of policy planning and policy

Policy planning is a series of analysis and decision making under the guidance of the established principle, which requires the close cooperation between the decision maker and the decision maker. Generally speaking, the procedure of policy planning includes four parts, the policy goal, the policy design, the evaluation and the choice of policy. The main emphasis of policy legalization is to explain the concept of legality from the legal point of view, it includes the legal decision-making 
subject, the legal procedure requirement, the policy content of the national constitution and the relevant laws and the legal system. The subject of policy planning has a single type, which is also known as the internal planning of the government system, there are multiple types, that is, policy planning to expand to the social field, performance for a variety of legal intervention.

\section{The Theoretical Basis of Public Policy Making Mechanism: Local Governance Theory and New Public Service Theory}

\section{Local Governance Theory}

Local governance theory is the product of the basic idea of contemporary governance theory, which is the combination of governance ideas and local administrative reform and public affairs management mode. Local governance refers to the public service and social affairs management reform and development process of the public service and social affairs management, which is based on the multi level and complex geographical space, which is close to the public life.

\section{New Public Service Theory}

The new public service theory emphasizes to citizens as the service object, advocating the diversification of the subject government public management as well as the pluralistic participation. Its essence is to implement the 'citizen oriented' government management, which is based on the different preferences of citizens to meet the specific needs of citizens for public goods and services as the goal. It is a theory of citizen participation in the process of public problem solving.

\section{Case Study: the Improvement and Innovation of Resettlement Policy in Jiangxi Province}

Emancipist is a large pet special social groups, both high-risk and vulnerable to the dual attributes. Strengthen and innovate the management of emancipist is of vital importance to prevent and reduce the crime. From the beginning of 2009, the Jiangxi Provincial Department of justice actively explore the practice, to establish a settlement admonishing seamless docking mechanism, the rate of emancipist re-crime decreased from $2.7 \%$ to $1.51 \%$. Jiangxi Provincial Department of justice was awarded the seventh China local government innovation award.

\section{The Status of China's Resettlement Policy}

CRI \& poetl staff resettlement work is an important part of the comprehensive management of social security work, is to maintain social stability, protect the legitimate rights and interests of the CRI \& poetl personnel, the CRI \& poetl personnel returning to the society for help and continuing education is an important measure. Our country resettlement policy has the following problems:

Problem of Placement Employment

The employment problem is a key and difficult job placement assistance and education at present, mainly due to the following reasons:

The employment situation is grim. The society of laid-off workers continue to increase, to the social re employment project brings the enormous pressure, the increasingly acute contradiction of employment. Under the current employment situation, the CRI \& poetl personnel resettlement work is very difficult. Skills are required to improve. CRI \& poetl staff there are older, low level of knowledge, the lack of labor skills and other characteristics, so their placement difficulty. What's more, as the influence of the traditional concept, quite a few people even look down upon them with discrimination. Some people put the CRI \& poetl staff resettlement work just in oral above is the general form, many units would not receive these people.

\section{Problem of Connection Management}

The biggest problem caused by the difficulty of connection management is the separation of people. According to this year emancipist special survey, part of the CRI \& poetl personnel return to society as a whole, due to changes in the household registration of residence, causing the separation of families, difficult to find, resulting in there are several reasons for this situation:

The main reason for the separation is removal. What's more part of the CRI \& poetl personnel's parents, brothers and sisters refuse to contact with them, which will cause a situation of homelessness. Other CRI \& poetl people are not willing to share their past to others, so they do not 
take the initiative to the police station to register and to judicial report. Part of the CRI \& poetl people do not return to their places of origin ,which leave a great difficulty on management.

Problem of Management System

As the working responsibility and authority is not legal, there are no definite and specific laws, legal support, the management relies only on a different departments in charge of policy documents. What's more, thee management personnel, management institutions, management funds are neither specific nor clear, so there is no fixed security.

\section{The improvement and innovation of resettlement in Jiangxi Province}

Carry Out the Work of Resettlement Policy Support:

The placement of corporate tax incentives is provided. 'On further improving the CRI \& poetl staff promotion of employment and social security work opinions' and the Ministry of Finance and the State Administration of Taxation jointly issued the 'on the support and promotion of employment related tax policy notice'.

The placement of business and industrial policy is provided. To this end, the document is issued by the State Administration for Industry and Commerce in 2010 "on the further development of social security comprehensive management and the construction of spiritual civilization. Preferential employment resettlement object is provided. The Ministry of human resources and social security for the introduction of the 'on Further Doing a good job in released from reeducation through labor placement assistance and education work of the notice', the relevant personnel provide the promotion of employment support policies.

Self employment resettlement object is encouraged. Relevant provisions of the relevant provisions of the circular on supporting and promoting employment related tax policy. Give full play to the association of self-employed, private enterprise association, and strengthen of ex convict personnel initiate individual industrial and commercial households or private sector guidance management.

Temporary assistance and social security measures:

Civil affairs departments to meet the urban and rural residents, rural five guarantees supporting policy after serving a sentence release personnel timely into the scope of protection, implement the security benefits; not conforming to the urban and rural subsistence allowances, rural five conditions difficult resettlement object, take the temporary relief measures, give necessary assistance; to comply with the conditions of medical assistance included in prevalence and resettlement object, but also give the necessary medical assistance, to finance its participation in medical insurance and new rural cooperative medical system, after medical insurance or NCMS reimbursement of medical expenses, the civil affairs department to give the necessary assistance.

\section{Results and discussion}

Due to the various characteristics of different provinces and cities, Jiangxi provides us a new perspective on the innovation of resettlement.

In Jiangxi Province of resettlement policy of creativity and perfect the formulation process, which relates to the from the central government to the local departments multiple units to participate in collaborative. First central comprehensive management entrusted with the introduction of a departmental regulatory document way, timely for resettlement work made to standardize and guide; departments according to the Central Committee for comprehensive management of public security requirements will alone or in combination with the introduction of relative specific implementation details. In addition, Jiangxi Province resettlement policy construction process also local enterprises, association of self-employed, private enterprise association involved, through the employment and self employment preferential to released from prison, thereby reducing the released prisoners in the crime rate, effectively improve the local economic benefits, so as to realize the internal and external cooperation to achieve a win-win situation.

In the process of the formulation of the policy, it also involves the analysis and discussion of the public interest, the government role as well as the role of the citizen. In resettlement policy 
formulation process, the public interest than the aggregation of individual interests, released prisoners have been properly resettled, employment, self employment, entrepreneurship and other various aspects both support policy, the stability of the released prisoners, can realize Jiangxi Province ex convict personnel crime rate decreases, the effective protection of social order and stability, and entrepreneurship and to promote the development of the local economy, enhance economic efficiency, policy formulation in the process of the realization of public interests is a win-win results. Government and government departments at all levels in Jiangxi province play a dual role in the process of policy formulation, on the one hand, as the main body of the policy formulation of innovation and improvement, on the other hand to encourage government organizations, private organizations, social organizations and civil society organizations and other organizations to participate in the policy formulation of the network system. And local enterprises, individual workers associations, private enterprises association also actively participate in, as the administrative state of their own citizens to participate in governance, the pursuit of greater benefits and all levels of government to take action.

\section{Acknowledgement}

This research was financially supported by the National Natural Science Foundation of China (Grant NO. 71473229) and Zhejiang Provincial Natural Science Foundation of China(Grant NO. LQ14G030024).

\section{References}

[1] Public Policymaking Reexamine (San Francisco: Chandler, 1968, 1983 Transaction Books enlarged edition)

[2] CHEN Zhen-ming. Policy science: an introduction to public policy analysis [M]// China Renmin University Press,1998

[3] SUN Bo-ying. Contemporary Local Governance: facing the challenges of the twenty-first Century [M]. China Renmin University Press,2004.33、65.

[4] Jackson, M. W. The Public Interest, Public Service And Democracy[J]. Australian Journal of Public Administration, 1988, 47(3):241-251.

[5] WEI Ai-hua. Study on the legislative procedures of local government regulations [D]. Southwest University of Political Science and Law,2009.

[6] Denhardt R B, Denhardt J V. The new public service: Serving rather than steering[J]. Public administration review, 2000, 60(6): 549-559.

[7] New public management: the transformation of ideas and practice[M]. Ashgate Pub Limited, 2002.

[8] Hope K R. Decentralisation and local governance theory and the practice in Botswana[J]. Development Southern Africa, 2000, 17(4): 519-534.

[9] Goodwin M, Painter J. Local governance, the crises of Fordism and the changing geographies of regulation[J]. Transactions of the Institute of British Geographers, 1996: 635-648.

[10] Stoker G. Governance as theory: five propositions[J]. International social science journal, 1998, 50(155): 17-28. 